\title{
PENGARUH METODE AKTIF REFLEKTIF TERHADAP MENULIS LAPORAN PERJALANAN SISWA KELAS VII SMP BINA PUTRA SEPATAN TIMUR
}

\author{
Siti Nur'Aidah ${ }^{1}$, Ira Anisa Purawinangun ${ }^{2}$ \\ Universitas Muhammadiyah Tangerang \\ sitinuraidah.sna06@gmail.com
}

\begin{abstract}
ABSTRAK
Penelitian ini dilatar belakangi oleh kurangnya pengalaman siswa seperti kosakata dan kurangnya pemahaman tentang struktur menulis laporan perjalanan. Metode pembelajaran yang digunakan membuat siswa merasa bosan dan kurang termotivasi. Salah satu metode pembelajaran yang sesuai dengan kemampuan menulis laporan perjalanan adalah metode pembelajaran Aktif Reflektif. Hasil penelitian ini menunjukkan adanya kemampuan menulis laporan perjalanan menggunakan metode pembelajaran konvensional menunjukkan hasil $t_{\text {hitung }}$ $(2,040)<\mathrm{t}_{\text {tabel }}(2,042), \mathrm{t}_{\text {hitung }}$ lebih kecil dari $\mathrm{t}_{\text {tabel, }}$, ini menunjukkan bahwa tidak ada perbedan yang signitifan antara siswa kelas kontrol dan eksperimen dalam kemampuan menulis laporan perjalanan di pretes. Setelah pretes dilakukan untuk mengetahui peningkatan kemampuan menulis laporan perjalanan siswa dilakukan postes. Hasil penelitian postes diketahui $t_{\text {hitung }}$ $(4,255)>t_{\text {tabel }}(2,042)$, $t_{\text {hitung }}$ lebih besar dari $t_{\text {tabel, }}$ ini menunjukkan bahwa terdapat peningkatan antara kemampuan menulis laporan perjalanan dengan menggunakan metode pembelajaran Aktif Reflektif dan siswa yang hanya menerima pembelajaran konvensional. Dengan demikian, dapat disimpulkan bahwa setelah menggunakan metode pembelajaran Aktif Reflektif pada kelas eksperimen kemampuan menulis laporan perjalanan siswa lebih baik.
\end{abstract}

Kata kunci : metode Aktif Reflektif, menulis laporan

\section{A. PENDAhuluan}

Aspek keterampilan berbahasa yang digunakan sebagai salah satu alat komunikasi yang efektif yaitu keterampilan menulis karena dengan tulisan seseorang dapat menyampaikan gagasannya ke setiap orang tanpa dibatasi oleh waktu. Menulis dapat dipisahkan dengan keterampilan berbahasa yang lainnya seperti berbicara, membaca, dan menyimak. Keempat aspek keterampilan tersebut harus seimbang dalam proses dapat tercapai secara optimal. Menurut Tarigan (2008:3), “Kegiatan menulis merupakan suatu keterampilan berbahasa yang digunakan untuk berkomunikasi secara tidak langsung, tidak secara tatap muka dengan orang lain. Menulis merupakan suatu kegiatan yang produktif dan ekspresif." Produktif dan ekspresif mengandung arti sebagai penyampaian informasi secara tidak langsung. Dikatakan produktif karena kegiatan menulis adalah kegiatan yang menghasilkan sebuah karya tulis yang berupa hasil ungkapan-ungkapan pikiran seseorang.

Berdasarkan observasi praktik menulis di kelas VII SMP Bina Putra Sepatan Timur. menunjukan kualitas pembelajaran menulis siswa tergolong rendah. Siswa lebih 
mementingkan panjang karangan dibandingkan kualitas karangan. Padahal keterampilan menulis merupakan kegiatan yang melahirkan pikiran dan perasaaan melalui bahasa tulisan. Hal ini disebabkan oleh minat menulis siswa SMP yang masih rendah, dan dianggap sulit. Selain itu, pemakaian metode pembelajaran yang kurang efektif oleh guru sehingga tidak tepat pada sasaran.

Maka, peneliti melakukan sebuah penelitian pada keterampilan menulis proposal perjalanan menggunakan metode Aktif Reflektif. Metode Aktif Reflektif yaitu bagian dari salah satu tipe pembelajaran Cooperative Learning. Metode Aktif Reflektif pada prinsipnya adalah menggabungkan metode pembelajaran aktif (active learning) dan metode pembelajaran reflektif (reflective learning). Metode Aktif Reflektif adalah cara cepat untuk merangsang munculnya potensi menulis dengan bantuan objek dalam merefleksikan pengalaman pribadi dalam bentuk tulisan. Secara pedagogis pembelajaran aktif adalah proses pembelajaran yang tidak hanya mendengarkan dan mencatat. Pembelajaran aktif adalah proses pembelajaran yang melibatkan siswa dalam melakukan sesuatu dan berpikir tentang apa yang akan mereka lakukan. Pembelajaran aktif mendasarkan pada asumsi, pembelajaran pada dasarnya adalah pencarian secara aktif pengetahuan dan setiap orang belajar dengan cara yang berbeda, sedangkan pembelajaran reflektif memberikan kesempatan kepada siswa untuk melakukan analisis atau pengalaman individual yang dialami dan memfasilitasi pembelajaran dari pengalaman tersebut. Pembelajaran reflektif mendorong peserta didik untuk berpikir kreatif, mempertanyakan sikap, dan mendorong kemandirian pembelajar.

Penerapan metode Aktif Reflektif terhadap menulis laporan perjalanan pada siswa kelas VII SMP Bina Putra Sepatan Timur diharapkan dapat mengatasi kesulitan siswa dalam menulis sebuah karangan maupun pengalaman pribadi. Pembelajaran metode Aktif Reflektif ini mengaitkan antara materi dengan situasi dunia nyata ke siswa. Dengan demikian, siswa diharapkan mampu menguasai diri sendiri dan menciptakan langkah-langkah yang besar untuk mencapai suatu perubahan yang lebih baik dan menghasilkan suatu perbedaan besar suatu saat nanti. Tujuan penelitian ini yaitu pengaruh kemampuan menulis laporan perjalanan siswa dengan menggunakan metode pembelajaran Aktif Reflektif di kelas VII SMP Bina Putra Sepatan Timur.

\section{B. KAJIAN TEORI}

Kegiatan menulis merupakan suatu keterampilan berbahasa yang digunakan untuk berkomunikasi secara tidak langsung, artinya tidak secara tatap muka dengan orang lain, melainkan melalui media tulis. Saleh (2013:31) yang mengemukakan bahwa "Menulis adalah 
rangkaian kegiatan seseorang yang meliputi pengungkapan ide-ide, gagasan, buah pikiran, pendapat yang baru, yang bersumber dari pengalaman nyata penulisannya, dengan menggunakan kata-kata yang baik, disusun secara kronologis dengan menggunakan kalimat yang jelas, dan paragraf yang baik serta ditulis dengan menggunakan PUEBI yang benar, sehingga dapat dipahami oleh orang lain/pembaca." Penulis harus mampu berpikir secara tepat untuk memilih kata dan juga variasi kalimat yang akan digunakan sehingga tulisannya dapat dipahami oleh pembaca.

Adapun menurut Dalman (2016:3), "Menulis merupakan suatu kegiatan komunikasi berupa penyampaian pesan (informasi) secara tertulis kepada pihak lain dengan menggunakan bahasa tulis sebagai alat atau medianya." Menulis merupakan proses penyampaian pikiran, angan-angan, perasaan dalam bentuk lambang/tanda yang bermakna dengan menggunakan bahasa tulis yang dijadikan sebagai alat atau media media untuk menyampaikan pesan kepada para pembaca. Keterampilan menulis memiliki fungsi-fungsi yang dikemukakan oleh Nurjamal (2011:72) yaitu a) menginformasikan sesuatu kepada pembaca, 2) meyakinkan pembaca, 3) mengajak pembaca, 4) menghibur pembaca, 5) melarang atau memerintah pembaca, 6) mendukung pendapat orang lain, 7) menolak atau menyanggah pendapat orang lain (h. 72).

Secara umum metode Aktif Reflektif merupakan konsep belajar yang membantu guru mengaitkan materi yang diajarkan ke situasi yang nyata. Dengan demikian, dapat mendorong siswa untuk menghubungkan antara pengetahuan yang dimiliki dengan penerapan dalam kehidupan sehari-hari, baik keluarga, teman maupun lingkungan itu sendiri.Menurut Silberman (2013:9) dalam pembelajaran Active Learning "Belajar aktif adalah pembelajaran dengan menggunakan otak untuk mengkaji gagasan, memecahkan masalah, dan menerapkan apa yang dipelajari. Belajar aktif haruslah menyenangkan, bersemangat, dan penuh gairah. Siswa bahkan sering meninggalkan tempat duduk mereka, bergerak leluasa dan berpikir keras (Moving about dan thinking aloud). ”. Untuk bisa mempelajari sesuatu dengan baik, kita perlu mendengarnya, melihatnya, mengajukan pertanyaan, dan membahasnya dengan orang lain. Bukan cuma itu, siswa perlu mengerjakannya yakni menggambarkan sesuatu dengan cara mereka sendiri, menunjukkan contohnya, mencoba mempraktikan keterampilan, dan mengerjakan tugas yang menuntut pengetahuan yang telah atau harus mereka dapatkan.

\section{METODE PENELITIAN}

Metode penelitian yang digunakan dalam penelitian ini yaitu Quasi Eksperimen Design dengan bentuk Nonequalivalent Contro Group Design. Bentuk Nonequalivalent 
Contro Group Design pada penelitian ini menggunakan dua kelompok yang terdiri dari kelompok eksperimen yang diberi perlakuan dan kelompok kontrol yang diberi perlakuan konvensional sebagai pembanding. Pemilihan kelas eksperimen maupun kelas kontrol dipilih secara acak (random) karena alasan tertentu.

Populasi dalam penelitan ini adalah siswa kelas VII SMP Bina Putra Sepatan Timur yaitu kelas VIIA yaitu 30 siswa, kelas VIIB yaitu 30 siswa, kelas VIIC yaitu 28 siswa. Sampel dalam penelitian ini diambil dengan teknik Simple Random Sampling yaitu pengambilan sampel yang dilakukan secara acak tanpa memperhatikan strata yang ada. Sampel yang diambil dalam penelitian ini hanya ada 2 kelas dari 3 kelas yang ada di SMP Bina Putra Sepatan Timur yaitu kelas VIIA sebagai kelas eksperiman dan kelas VIIB sebagai kelas kontrol. Teknik pengumpulan data yaitu menggunakan tes essay. Teknik analisis data dalam penelitian kuantitatif terbagi dua teknik, yaitu menggunakan statistik deskriptif dan statistik inferensial. Untuk statistik inferensial terdapat statistik parametrik dan non parametrik. Pengujian terhadap perbedaan rata-rata hasil postest menggunakan teknik statistik uji t test.

\section{PEMBAHASAN}

Penelitian ini telah dilakukan oleh peneliti di Yayasan Pembina Lembaga Pendidikan SMP Bina Putra Sepatan Timur. Penelitian ini mengenai Metode Pembelajaran Berbasis Proyek atau Metode Aktif Reflektif pada pembelajaran Bahasa Indonesia pokok bahasa menulis laporan perjalanan kelas VII (tujuh). Dalam penelitian ini terdapat dua kelompok, yaitu kelompok eksperimen yang berjumlah 30 siswa yang diajarkan dengan menggunakan metode pembelajaran Aktif Reflektif, dan kelompok kontrol yang berjumlah 30 siswa yang diajarkan dengan metode konvensional.

Tes ini diberikan kedua kelompok, setelah menyelesaikan pokok bahasan mengenai materi menulis laporan perjalanan, dimana dalam proses pembelajarannya kedua kelompok siswa diberikan perlakuan yang berbeda. Berikut adalah pemerolehan nilai siswa SMP Bina Putra Sepatan Timur berupa data nilai hasil belajar siswa materi menulis laporan perjalanan kelas kontrol dan kelas eksperimen pretes dan postes. Berikut ini adalah deskripsi pengolahan data secara kuantitatif diolah menjadi statistik.

Tabel 4.1 Tabel Distribusi Frekuensi Pretes Kelas Kontrol

\begin{tabular}{|c|c|c|c|c|}
\hline \multirow{2}{*}{ Kelas } & Interval & Tepi Kelas & Frekuensi & $\begin{array}{c}\text { Frekuensi Relatif } \\
\text { (fr) 100\% }\end{array}$ \\
\cline { 2 - 3 } & BBK-BAK & & 2 & $6.66 \%$ \\
\hline 1 & $20-29$ & $19.5-29.5$ & 11 & $36.66 \%$ \\
\hline 3 & $30-39$ & $29.5-39.5$ & 10 & $33.33 \%$ \\
\hline
\end{tabular}




\begin{tabular}{|c|c|c|c|c|}
\hline 4 & $50-59$ & $49.5-59.5$ & 4 & $13.33 \%$ \\
\hline 5 & $60-69$ & $59.5-69.5$ & 2 & $6.66 \%$ \\
\hline 6 & $70-79$ & $69.5-79.5$ & 1 & $3.33 \%$ \\
\hline \multicolumn{3}{|c|}{ JUMLAH } & 30 & $100 \%$ \\
\hline
\end{tabular}

Berdasarkan tabel 4.1 diperoleh hasil kemampuan menulis laporan perjalanan dalam menggunakan metode konvensional kelas kontrol pretes, siswa yang memperoleh hasil kemampuan menulis laporan perjalanan dibawah rata-rata ada 27 siswa dan yang memperoleh nilai diatas rata-rata ada 3 siswa.

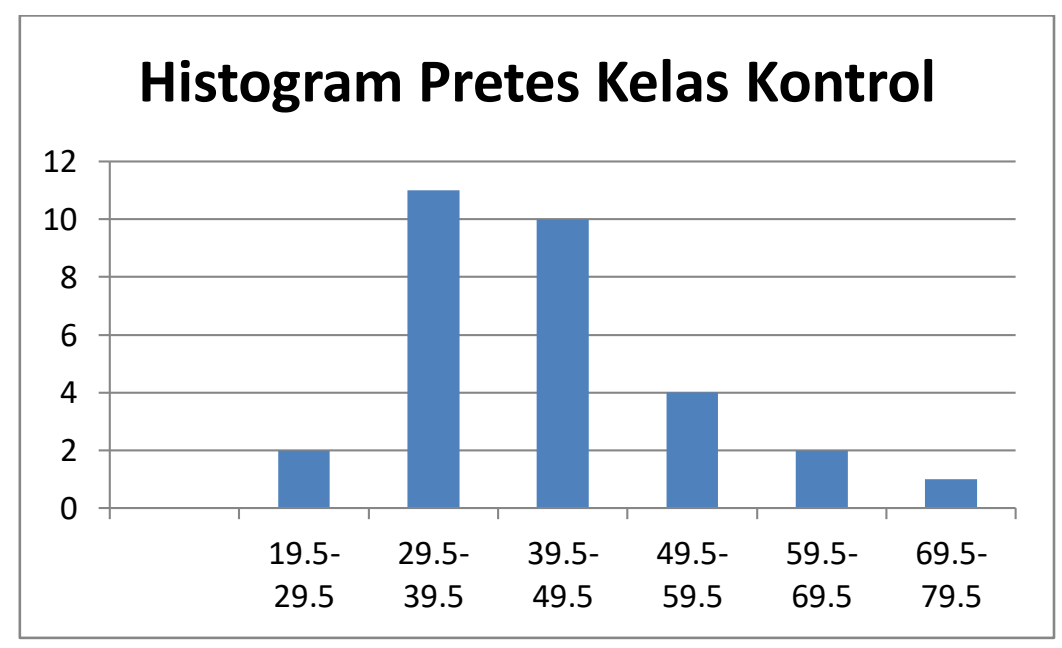

Gambar 4.1 Histogram Pretes Kelas Kontrol

Hasil belajar kemampuan menulis laporan perjalanan kelas postes kontrol diperoleh dengan menghitung pemerolehan nilai, pada kelas kontrol postes terdiri dari 30 siswa. Nilai terendah yaitu 20, nilai tertinggi 75 , rentang nilai 55, banyak kelas 3, interval kelas 10 . Maka distribusi frekuensi hasil data postes kontrol menulis laporan perjalanan kelas dapat dilihat dalam tabel berikut:

Tabel 4.2 Tabel Distribusi Frekuensi Postes Kelas Kontrol

\begin{tabular}{|c|c|c|c|c|}
\hline \multirow{2}{*}{ Kelas } & Interval & Tepi Kelas & Frekuensi & $\begin{array}{c}\text { Frekuensi Relatif (fr) } \\
\mathbf{1 0 0 \%}\end{array}$ \\
\cline { 2 - 3 } & BBK-BAK & & 1 & $3.33 \%$ \\
\hline 1 & $20-29$ & $19.5-29.5$ & 1 & $3.33 \%$ \\
\hline 2 & $30-39$ & $29.5-39.5$ & 4 & $13.33 \%$ \\
\hline 3 & $40-49$ & $39.5-49.5$ & 12 & $40 \%$ \\
\hline 4 & $50-59$ & $49.5-59.5$ & 7 & $23.33 \%$ \\
\hline 5 & $60-69$ & $59.5-69.5$ & 5 & $16.66 \%$ \\
\hline 6 & $70-79$ & $69.5-79.5$ & $\mathbf{3 0}$ & $\mathbf{1 0 0} \%$ \\
\hline
\end{tabular}

Berdasarkan tabel 4.2 diperoleh hasil kemampuan menulis laporan perjalanan dengan menggunakan metode konvensional kelas kontrol postes, siswa yang memperoleh hasil kemampuan menulis laporan perjalanan dibawah rata-rata ada 25 siswa dan yang memperoleh nilai diatas rata-rata ada 5 siswa. 


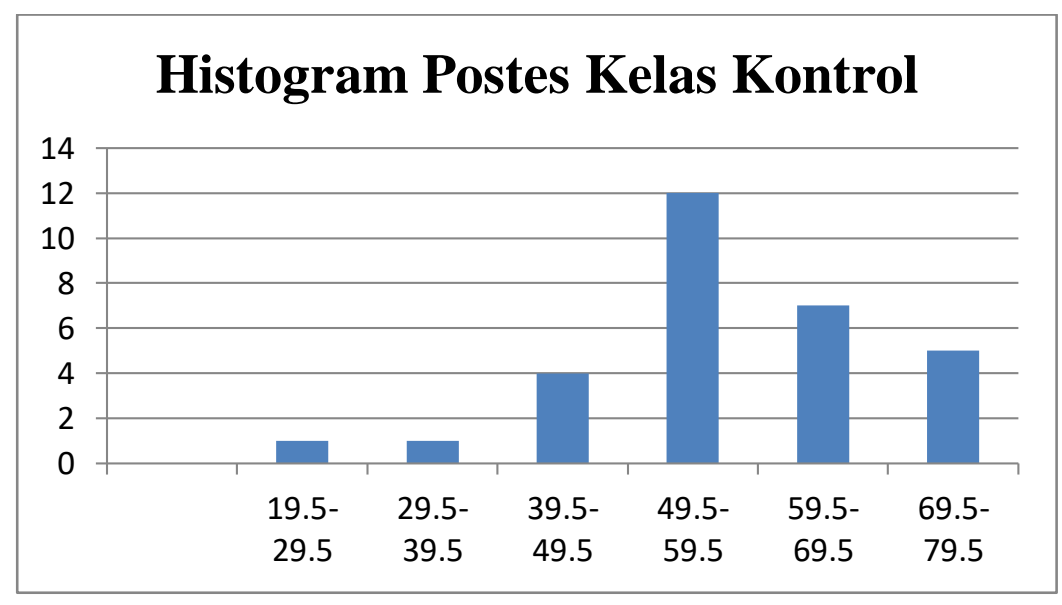

Gambar 4.2 Histogram Postes Kelas Kontrol

Hasil belajar kemampuan menulis laporan perjalanan kelas pretes eksperimen diperoleh dengan menghitung pemerolehan nilai, pada kelas eksperimen pretes terdiri dari 30 siswa, dengan perolehan nilai berbeda pada setiap kelas. Nilai terendah yaitu 30, nilai tertinggi 75, rentang data 45, banyak kelas 3 interval kelas 8. Maka distribusi frekuensi hasil data pretes eksperimen menulis laporan perjalanan kelas dapat dilihat dalam tabel berikut:

Tabel 4.3 Tabel Distribusi Frekuensi Pretes Kelas Eksperimen

\begin{tabular}{|c|c|c|c|c|}
\hline Kelas & $\begin{array}{c}\text { Interval } \\
\text { BBK-BAK }\end{array}$ & Tepi Kelas & Frekuensi & $\begin{array}{l}\text { Frekuensi Relatif } \\
\text { (fr) } 100 \%\end{array}$ \\
\hline 1 & $30-37$ & $29.5-37.5$ & 10 & $33.33 \%$ \\
\hline 2 & $38-45$ & $37.5-45.5$ & 7 & $26.66 \%$ \\
\hline 3 & $46-53$ & $45.5-53.5$ & 2 & $6.66 \%$ \\
\hline 4 & $54-61$ & $53.5-61.5$ & 7 & $20 \%$ \\
\hline 5 & $62-69$ & $61.5-69.5$ & 3 & $10 \%$ \\
\hline 6 & $70-77$ & $69.5-77.5$ & 1 & $3.33 \%$ \\
\hline \multicolumn{3}{|c|}{ JUMLAH } & 30 & $100 \%$ \\
\hline
\end{tabular}

Berdasarkan tabel 4.3 diperoleh hasil kemampuan menulis laporan perjalanan dengan menggunakan metode konvensional kelas eksperimen pretes, siswa yang memperoleh hasil kemampuan menulis laporan perjalanan dibawah rata-rata ada 19 siswa dan yang memperoleh nilai diatas rata-rata ada 11 siswa. 


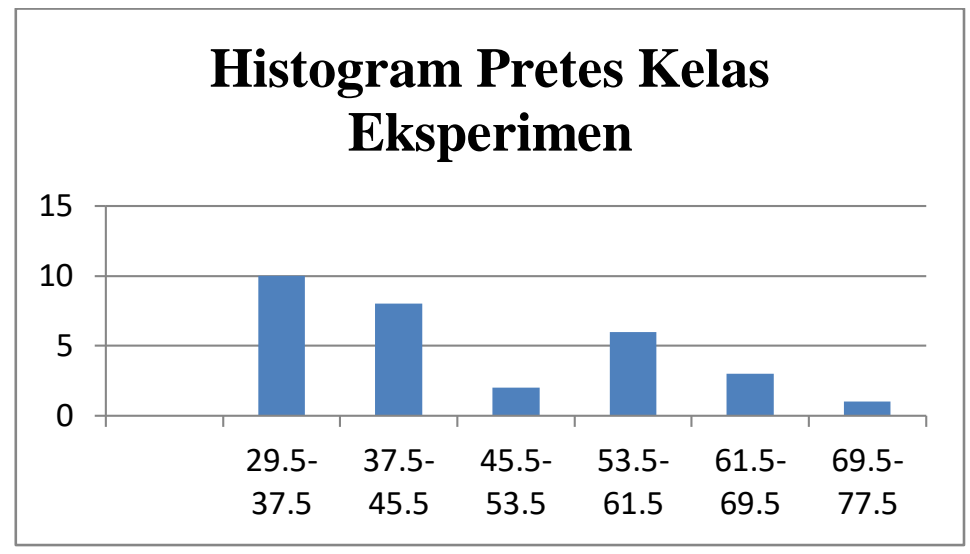

Gambar 4.3 Histogram Pretes Kelas Eksperimen

Hasil belajar kemampuan menulis laporan perjalanan kelas postes eksperimen diperoleh dengan menghitung perolehan nilai, pada kelas eksperimen pretes terdiri 30 siswa, dengan perolehan nilai berbeda pada setiap kelas. Nilai terendah yaitu 50, nilai tertinggi 90, rentang data 40, banyak kelas 3, interval kelas 7. Maka distribusi frekuensi hasil data pretes eksperimen menulis laporan perjalanan kelas dapat dilihat dalam tabel berikut:

\section{Tabel 4.4 Tabel Distribusi Frekunsi Postes Kelas Eksperimen}

\begin{tabular}{|c|c|c|c|c|}
\hline \multirow{2}{*}{ Kelas } & Interval & Tepi Kelas & Frekuensi & $\begin{array}{c}\text { Frekuensi Relatif } \\
\text { (fr) 100\% }\end{array}$ \\
\cline { 2 - 3 } & BBK-BAK & & 3 & $10 \%$ \\
\hline 1 & $50-56$ & $49.5-56.5$ & 6 & $20 \%$ \\
\hline 2 & $57-62$ & $56.5-62.5$ & 6 & $6.66 \%$ \\
\hline 3 & $63-69$ & $62.5-69.5$ & 2 & $30 \%$ \\
\hline 4 & $70-76$ & $69.5-76.5$ & 9 & $16.66 \%$ \\
\hline 5 & $77-83$ & $76.5-83.5$ & 5 & $16.66 \%$ \\
\hline 6 & $84-90$ & $83.5-90.5$ & 5 & $\mathbf{1 0 0} \%$ \\
\hline \multicolumn{3}{|c|}{ JUMLAH } & $\mathbf{3 0}$ & \\
\hline
\end{tabular}

Berdasarkan tabel 4.4 diperoleh hasil kemampuan menulis laporan perjalanan dengan menggunakan metode pembelajaran Aktif Reflektif kelas eksperimen postes, siswa yang memperoleh hasil kemampuan menulis laporan perjalanan dibawah rata-rata ada 3 siswa dan yang memperoleh nilai diatas rata-rata ada 27 siswa. 


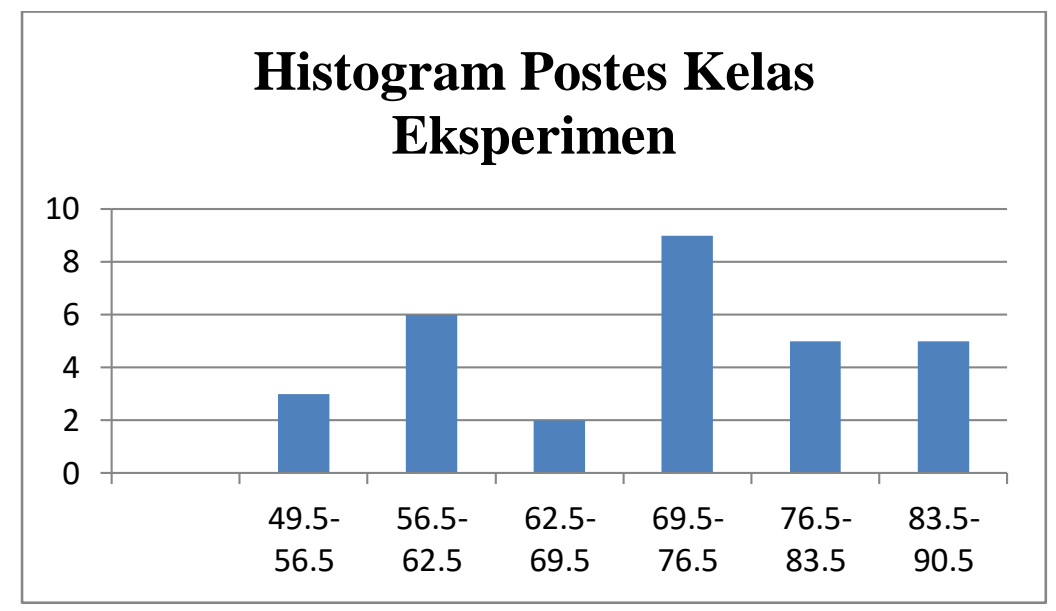

\section{Gambar 4.7 Histogram Postes Kelas Eksperimen}

Dari gambar grafik tersebut menunjukkan bahwa siswa yang memperoleh nilai dibawah rata-rata lebih sedikit dibandingkan dengan siswa yang memperoleh nilai diatas ratarata.

Tabel 4.5 Perolehan Nilai Uji Normalitas

\begin{tabular}{|c|l|c|c|c|c|}
\hline \multicolumn{2}{|c|}{ Uji Normalitas } & $\mathbf{N}$ & $\boldsymbol{X}_{\text {hitung }}$ & $\boldsymbol{X}_{\text {tabel }}$ & Keterangan \\
\hline \multirow{2}{*}{ Pretes } & Kelas Kontrol & & & $(0,05: 5)$ & \\
\cline { 2 - 6 } & & & 5,66 & 11,07 & Normal \\
\hline \multirow{3}{*}{ Postes } & Kelas Eksperimen & 30 & 1,09 & $10,05: 5)$ & Normal \\
\cline { 2 - 6 } & & & & $(0,05: 5)$ & Normal \\
\cline { 2 - 6 } & Kelas Kontrol & 30 & 5,83 & 11,07 & Normal \\
\cline { 2 - 6 } & & & & $(0,05: 5)$ & 11,07 \\
\hline
\end{tabular}

Uji homogenitas dilakukan untuk mengetahui apakah varians kelas eksperimen dan varians kelas kontrol homogen atau heterogen setelah data tersebut berdistribusi normal dengan menggunakan rumus uji $\mathrm{F}$ (uji fisher). Perhitungan nilai $\mathrm{F}$ dengan rumus :

$$
\mathrm{F}=\frac{\text { S2 terbesar }}{\text { S2 terkecil }}
$$

Perhitungan homogenitas pada kelas pretes kontrol, pretes eksperimen dan postes kontrol, postes eksperimen dengan uji F (Uji Fisher) dapat dilihat pada tabel di bawah ini :

Tabel 4.7 Perolehan Nilai Uji Homogenitas

\begin{tabular}{|c|c|c|c|c|}
\hline \multicolumn{2}{|c|}{ Sumber Varians } & $\mathbf{F}_{\text {hitung }}$ & $\mathbf{F}_{\text {tabel }}$ & Keterangan \\
\hline Kelas Pretes & Kontrol dan Eksperimen & 1,15 & 1,84 & Homogen \\
\hline Kelas Postes & Kontrol dan Eksperimen & 1,55 & 1,84 & Homogen \\
\hline
\end{tabular}


Dari tabel di atas diperoleh nilai pretes kontrol dengan eksperimen 1,15 lebih kecil dari $\mathrm{F}_{\text {tabel }}$ 1,84 maka dapat disimpulkan bahwa data tersebut berasal dari populasi yang homogen. Sedangkan nilai pada kelas postes kontrol dan eksperimen 1,55 lebih kecil dari $\mathrm{F}_{\text {tabel }}$ 1,84 maka dapat disimpulkan bahwa data berasal dari populasi yang homogeny. Setelah diketahui sampel berdistribusi normal dan dalam kedaaan yang homogen, selanjutnya dilakukan dengan menggunakan uji-t dengan rumus :

$$
\mathrm{t}=\frac{x 1-x 2}{\sqrt{\frac{\left.(n 1-n 2) S 1^{2}+\mid n 1-1\right) S 2^{2}\left(\frac{1}{n 1}+\frac{1}{n 2}\right)}{n 1+n 2-2}}}
$$

Karena $\mathrm{n} 1=\mathrm{n} 2$ (jumlah kelompok pertama sama dengan jumlah sample kedua) dan sampel dalam keadaan homogen. Maka $\mathrm{dk}=\mathrm{n} 1+\mathrm{n} 2-2$. Dengan hipotesis sebagai berikut :

$\mathrm{H}_{0}$ : $\mathrm{T}_{\text {hitung }}<\mathrm{T}_{\text {tabel }}$ maka dapat disimpulkan tidak terdapat perbedaan antara kelas kontrol dengan kelas eksperimen.

$\mathrm{H}_{1}$ : $\mathrm{T}_{\text {hitung }}>\mathrm{T}_{\text {tabel }}$ maka dapat disimpulkan terdapat perbedaan antara kelas kontrol dengan kelas eksperimen.

Pada masing-masing kelas memiliki jumlah siswa yang sama, kelas kontrol terdiri dari 30 siswa, kelas eksperimen terdiri dari 30 siswa. Perolehan untuk uji-t kelas pretes kontrol dengan eksperimen didapat 2,040 dengan $t_{\text {tabel }}$ 2,042 maka dapat disimpulkan bahwa tidak terdapat perbedaan menulis laporan perjalanan antara kelas kontrol dengan eksperimen karena $\mathrm{t}_{\text {tabel }}$ lebih besar. Sedangkan kelas postes kontrol dan eksperimen didapat 4,255 dengan $\mathrm{t}_{\text {tabel }}$ 2,042, maka dapat disimpulkan terdapat perbedaan menulis laporan perjalanan dengan menggunakan metode pembelajaran Aktif Reflektif antara kelas postes kontrol dan eksperimen.

Dari hasil pengujian hipotesis dengan menggunakan uji-t diperoleh $t_{\text {hitung }}$ sebesar 4,255 dan $t_{\text {tabel }}$ 2,042. Dengan demikian dapat dilihat bahwa $t_{\text {hitung }}>t_{\text {tabel, }}$ maka $H_{0}$ ditolak dan $H_{1}$ diterima, sehingga dapat disimpulkan bahwa terdapat perbedaan menulis laporan perjalanan antara siswa yang diberi metode pembelajaran Aktif Reflektif dengan siswa yang diberi metode konvensional.

Penelitian ini menggunakan metode kuantitatif yaitu dengan menggunakan statistik dari hasil observasi aktivitas anak untuk mengetahui kemampuan menulis laporan siswa kelas VII dengan menggunakan metode pembelajaran Aktif Reflektif. Pembahasan hasil penelitian ini untuk menunjukkan jawaban semua permasalahan dalam penelitian yaitu untuk mengetahui kemampuan menulis laporan mata pelajaran Bahasa Indonesia kelas VII dengan 
menggunakan metode pembelajaran Aktif Reflektif. Dari deskripsi data yang telah dikemukakan, tampak perkembangan atau kemajuan dalam menulis laporan perjalanan siswa yang menggunakan metode pembelajaran Aktif Reflektif terlihat lebih baik dari pada kemampuan menulis laporan siswa yang menggunakan metode konvensional. Hasil kemampuan menulis laporan siswa dengan menggunakan metode pembelajaran Aktif Reflektif memiliki mean (nilai rata-rata) 71,4, median (nilai tengah) 74,36, modus sebesar 75,17, varians sebesar 450,3, dan simpangan baku sebesar 21,22. Sedangkan perolehan nilai hasil menulis laporan perjalanan siswa dengan menggunakan metode konvensional mean (nilai rata-rata) 57,6, median (nilai tengah) 54,5, modus sebesar 55,5, varians 288,8, dan simpangan baku sebesar 16,99 .

Hasil tersebut membuktikan bahwa siswa yang menggunakan metode pembelajaran Aktif Reflektif memperoleh nilai hasil lebih tinggi dari pada siswa yang diajar menggunakan metode konvensional. Hasil pengujian hipotesis uji-t menunjukkan secara signitifan bahwa nilai $t_{\text {hitung }}$ lebih besar dari nilai $t_{\text {tabel }}$. Dengan demikian dapat disimpulkan bahwa terdapat perbedaan terhadap kemampuan menulis laporan perjalanan siswa kelas VIII mata pelajaran Bahasa Indonesia.

\section{E. Kesimpulan dan Saran}

Berdasarkan hasil penelitian yang berjudul "Penggunaan Metode Aktif Reflektif Terhadap Menulis Laporan Perjalanan Siswa Kelas VII SMP Bina Putra Sepatan Timur" bahwa permasalahan dilatar belakangi karena nilai kemampuan menulis laporan perjalanan yang berada di bawah KKM. Hal tesebut dikarenakan beberapa faktor salah satunya yaitu penggunaan metode pembelajaran yang membuat siswa merasa jenuh dengan materi menulis laporan. Penelitian ini bertujuan untuk mengetahui apakah terdapat perbedaan ketika siswa diberikan motode pembelajaran Aktif Reflektif dengan siswa yang diberikan metode konvensional.

Setelah pengambilan data dilakukan pada saat pretes diperoleh nilai rata-rata kelas kontrol yaitu 43,6, dan kelas eksperimen 46,5. Pada saat postes diperoleh nilai rata-rata kelas kontrol yaitu 57,6 dan kelas eksperimen yaitu 71,4 yang menunjukkan bahwa terdapat perbedaan nilai rata-rata antara siswa kelas kontrol dan kelas eksperimen.Hasil penelitian dapat disimpulkan bahwa perhitungan uji hipotesis dengan uji-t didapat perhitungan bahwa $t_{\text {hitung }}$ sebesar 4,255, sedangkan $t_{\text {tabel }}$ sebesar 2,042, maka $\mathrm{H}_{0}$ ditolak dan $\mathrm{H}_{1}$ diterima. Berdasarkan kemampuan menulis laporan perjalanan yang didapat, dapat disimpukan bahwa 
terdapat perbedaan menulis laporan perjalanan siswa yang diberikan metode pembelajaran Aktif Reflektif lebih baik dengan siswa yang diberikan metode kovensional.

Berdasarkan hasil penelitian yang telah dilakukan menunjukkan bahwa dengan menggunakan metode pembelajaran Aktif Reflektif dapat meningkatkan kemampuan menulis laporan siswa. Penerapannya dalam kelas dapat melatih siswa menjadi percaya diri dalam kemampuan menulisnya dan dapat meningkatkan keingintahuan lebih dalam bagaimana cara menulis laporan perjalanan yang benar. Dengan menggunakan metode pembelajaran Aktif Reflektif dapat membuat siswa lebih aktif di dalam kelas.

Berdasarkan temuan-temuan penelitian maka dapat dikemukakan beberapa saran dari penyusun sebagai perbaikan di masa mendatang yaitu 1) untuk mendapatkan hasil penelitian yang lebih baik, saat pembelajaran dimulai disarankan kepada guru untuk memberikan motivasi kepada siswa sebelum pembelajaran berlangsung, 2) jika guru ingin mendapatkan hasil belajar yang optimal, maka harus menggunakan metode pembelajaran yang berbeda salah satunya dengan metode pembelajaran yang membuat siswa lebih aktif di dalam kelas, 3) siswa diharapkan lebih memperhatikan dengan seksama saat pembelajaran berlangsung sehingga memperoleh pemahaman secara utuh dan menyeluruh mengenai materi yang disampaikan, 4) Bagi peneliti selanjutnya hendaknya dapat melakukan penelitian baru melalui metode atau media pembelajaran yang berbeda sehingga lebih maksimal dan akurat sesuai dengan tujuan yang diharapkan.

\section{F. Daftar Pustaka}

Dalman, M.Pd. (2016). Keterampilan Menulis. Jakarta: PT Grafindo Persada.

Nurjamal, Daeng., Sumirat Warta., \& Darwis Riadi. (2011). Terampil Berbahasa. Bandung: Alfabeta

Saleh, M.S \& Zuleha, H.M. (2013). Keterampilan Menulis Di Sekolah Dasar. Tangerang: Pustaka Mandiri.

Silberman, Melvin. (2013). Active Learning (101 Cara Belajar Siswa Aktif). Bandung: Nuansa.

Tarigan, Henry Guntur. (2008). Menulis Sebagai Suatu Keterampilan Berbahasa. Bandung: Angkasa. 